\title{
Clinical study of Misgav Ladach technique of caesarean section
}

\author{
Shrinivas N. Gadappa, Pratibha V. Dixit*, Deepika Sharma, Yogita Gavit
}

Department of Obstetrics and Gynecology, Government Medical College, Aurangabad, Maharashtra, India

Received: 04 October 2017

Accepted: 31 October 2017

\section{*Correspondence:}

Dr. Pratibha V. Dixit,

E-mail: dr.pratibha.dixit@gmail.com

Copyright: (C) the author(s), publisher and licensee Medip Academy. This is an open-access article distributed under the terms of the Creative Commons Attribution Non-Commercial License, which permits unrestricted non-commercial use, distribution, and reproduction in any medium, provided the original work is properly cited.

\begin{abstract}
Background: In the last decades caesarean section rates increased in many countries becoming the most performed intraperitoneal surgical procedure. The operative technique performed is made chiefly on the basis of the individual experience and preference of operators, the characteristics of patients, timing and urgency of intervention. Present study was undertaken to assess the benefits of the Misgav Ladach caesarean section technique in tertiary care hospital and evaluate the operative parameters like efficacy, safety, duration of surgery, blood loss, need for suture material, post-operative morbidity.

Methods: Prospective surgical interventional study conducted in department of obstetrics and gynecology in tertiary care institute.

Results: The duration of surgery, blood loss and post-operative complications were significantly less in the Misgav Ladach technique of LSCS.

Conclusions: The choice of the Caesarean section technique is strictly linked to the individual experience and confidence of the surgical team. Misgav-Ladach technique proved to be associated to less complications, moreover, since its shorter operating time; it is to prefer in all that cases a prompt operation is required.
\end{abstract}

Keywords: Caesarean section, Misgav Ladach, Post-operative morbidity

\section{INTRODUCTION}

Caesarean section is the commonest major surgical procedure in modern days and situations often demand its performance in the quickest possible operative time for fetal or maternal emergencies without compromising the surgical excellence. In today's world there is a continuous search for better and more satisfactory techniques for caesarean section.

Michel Stark from department of obstetrics and gynaecology in Misgav Ladach hospital in Jerusalem rationalized all new strategies and proposed the technique named the Misgav Ladach technique in1984. ${ }^{1}$ This method is concise very simple to perform operation for abdominal delivery of foetus with reduced morbidity and very short operative time. The main features of Misgav Ladach technique of caesarean section are transverse Joen
Cohen incision for opening the abdomen, suturing uterine incision in one layer and non-closure of visceral and parietal peritoneum. ${ }^{1}$

This is one of the changing trend in caesarean section, thus an attempt was made to evaluate this technique of LSCS in detail regards to technique and patient's benefit.

\section{METHODS}

It was prospective surgical interventional study carried out on 200 patients who underwent caesarean section at Government medical college Aurangabad after taking permission from institutional ethical committee.

200 cases were randomly selected whose complete blood count, blood grouping was known preoperatively. After taking a through history and complete general and 
abdominal examination was done, written informed consent was taken. Bladder was routinely catheterised before surgery. Prophylactic single dose of antibiotics injection Taxim $1 \mathrm{gm}$ intravenously was given half an hour prior to surgery. The choice of anaesthesia was governed by anaesthetist. On $3^{\text {rd }}$ post-operative day repeat haemoglobin levels were done.

\section{Inclusion criteria}

Indications of caesarean section by Misgav Ladach method of LSCS

- Fetal distress

- Cephalo-pelvic disproportion

- Previous LSCS with unfavorable cervix

- Deep transverse arrest

- Face presentation

- Breech presentation

- Brow presentation

- Compound presentation

- Cord presentation/prolapsed

- Transverse lie

\section{Exclusion criteria}

- Patient with known medical/ surgical illness (Hypertensive disorders of pregnancy, DIC, Liver disease etc.)

- Previous LSCS with vertical scar

- Previous two or more LSCS

- Placenta previa

\section{Salient features of method}

In this technique of caesarean section the incision is a straight transverse incision in the skin about $2-3 \mathrm{~cm}$ below the line between the anterior superior iliac spine; deepening the cut in the midline with scalpel to expose the fascia; dissecting fascia laterally by about $2 \mathrm{~cm}$, below the fat tissue with a slightly opened tip of the scissors. At this point, using index fingers the fascia is stretched caudally and cranially to make room for the next step and to find the midline separation of the rectus muscles. Both the surgeon and the assistant insert their index and third fingers under the muscles and stretch the muscles, fascia and subcutaneous fat tissue bilaterally, at the same time, until the required opening is achieved.

The peritoneum is opened by stretching with index fingers. The uterus is opened with an index finger and the hole enlarged between the index finger of one hand and the thumb on the other. The uterus is closed with a onelayer continuous locking stitch. The visceral and parietal peritoneal layers are left open. The rectus muscle is not stitched. The rectus sheath is stitched with a continuous non-locking stitch. The skin is closed with two or three mattress sutures. The space in between is apposed with non-traumatic forceps for 5 minutes.

\section{RESULTS}

The study was carried out in department of obstetrics and gynaecology GMCH Aurangabad for a period of two years. The baseline characteristics of patients who were included are shown below.

Table 1: The distribution of patients based on age index.

\begin{tabular}{|lll|}
\hline Age in years & Number of patients $(n=200)$ & $\%$ \\
\hline$<20$ & 80 & 40 \\
\hline $21-25$ & 101 & 50.5 \\
\hline $26-30$ & 18 & 09 \\
\hline$>30$ & 01 & 0.5 \\
\hline Total & 200 & 100 \\
\hline
\end{tabular}

In present study majority $(50.5 \%)$ of the cases who underwent, caesarean sections were in the age group of 21-25 years (Table 1). In the present series the maximum number of patients who underwent caesarean sections was primigravidae $(46.5 \%)$ followed by second gravid (38.5\%). Among these 54 patients were previous LSCS.

Table 2: Patient distribution on the basis of indication for LSCS.

\begin{tabular}{|lll|}
\hline Indication of LSCS & Number of patients & $\%$ \\
\hline Foetal distress & 72 & 36 \\
\hline CPD & 50 & 25 \\
\hline Breech & 25 & 12.5 \\
\hline $\begin{array}{l}\text { Previous LSCS with } \\
\text { unfavourable cervix }\end{array}$ & 21 & 10.5 \\
\hline Failure to progress & 08 & 4 \\
\hline Contracted pelvis & 08 & 4 \\
\hline Brow presentation & 04 & 2 \\
\hline Face presentation & 02 & 1 \\
\hline Oblique lie & 02 & 1 \\
\hline Compound presentation & 01 & 0.5 \\
\hline Deep transverse arrest & 03 & 1.5 \\
\hline Cord presentation & 01 & 0.5 \\
\hline Transverse lie & 03 & 1.5 \\
\hline Total & 200 & 100 \\
\hline
\end{tabular}

As shown in Table 2 the main indication for caesarean section was foetal distress $36 \%$ followed by Cephalopelvic disproportion in 25\% cases. Among 200 cases 186 (93\%) cases were emergency LSCS. In most of the cases spinal anaesthesia was used $(96.5 \%)$.

As shown in Table 3 in majority of cases skin incision to baby delivery time is 1-2 min. The mean duration of surgery was 26 minute 12 seconds.

The duration of surgery differed from surgeon to surgeon and it depends on operative skill of surgeon. In our study $52.5 \%$ LSCS were performed in $20-25 \mathrm{~min}$ and $37 \%$ required 25-30 $\mathrm{min}$. 
Table 3: Skin incision to baby delivery time.

\begin{tabular}{|lll|}
\hline $\begin{array}{l}\text { Time in } \\
\text { minute }\end{array}$ & $\begin{array}{l}\text { Number of patients } \\
(\mathrm{n}=200)\end{array}$ & Percentage \\
\hline $1-2$ & 141 & 70.5 \\
\hline $2.1-3$ & 45 & 24 \\
\hline $3.1-4$ & 7 & 3.5 \\
\hline$>4.1$ & 4 & 2.1 \\
\hline Total & 200 & 100 \\
\hline
\end{tabular}

Uterine closure was done in single layer. In $88.5 \%$ cases there was no requirement of additional haemostatic sutures in addition to single layer closure of the uterine incision. In $6 \%$ cases only one suture, $4 \%$ required 2 sutures and only 1 patient $(0.5 \%)$ required double layer closure of uterus.

Table 4: Post operative haemoglobin deficit.

\begin{tabular}{|lll|}
\hline $\begin{array}{l}\text { Haemoglobin } \\
\text { deficit in gm } \%\end{array}$ & $\begin{array}{l}\text { Number of } \\
\text { patients }(\mathbf{n = 2 0 0})\end{array}$ & Percentage \\
\hline$<1$ & 140 & 70 \\
\hline $1-2$ & 58 & 29 \\
\hline$>2$ & 02 & 01 \\
\hline Total & 200 & 100 \\
\hline
\end{tabular}

Haemoglobin deficit is indicator of intra operative blood loss. It is obtained by subtracting post operative haemoglobin level from preoperative haemoglobin. As shown in table $4,70 \%$ patients had hb deficit $<1 \mathrm{gm} \%$ and only $1 \%$ had hb deficit $>2 \mathrm{gm} \%$. Only $2 \%$ patients required blood transfusion, $1 \%$ due to pre-existing severe anaemia and $1 \%$ had postpartum haemorrhage.

Post operative morbidity: post operatively 4 patients were suffered from fever and 1 patient from urinary tract infection. In this method febrile morbidity is very low. In 1 patient fever is due to wound infection and in one patient is due to lower respiratory tract infection and in 2 patient cause of fever is unknown but fever subsided on its own on fourth postoperative day.

Table 5: Condition of wound at stitch removal.

\begin{tabular}{|lll|}
\hline Condition of wound & $\begin{array}{l}\text { Number of } \\
\text { patients }(\mathbf{n = 2 0 0})\end{array}$ & $\%$ \\
\hline Clean, healed, linear incision & 190 & 95 \\
\hline Serous discharge & 5 & 2.5 \\
\hline Purulent discharge & 1 & 0.5 \\
\hline Wound hematoma & 1 & 0.5 \\
\hline Superficial skin dehiscence & 3 & 1.5 \\
\hline Total & 200 & 100 \\
\hline
\end{tabular}

As shown in Table 5 only $5 \%$ patients had some wound complication out of which only 1 patient required secondary suturing. In present study 76 LSCS were done for the foetal distress out of which 40 babies had Apgar score $<5$ at $1 \mathrm{~min}$ and 2 babies remain depressed even after $10 \mathrm{~min}$, both babies died within 24 hours. There was no maternal mortality. All patients came for follow up 15 days and after one month. No complication was noted during follow up visit.

\section{DISCUSSION}

Many gynaecological operations are being replaced today by alternative medical and surgical development like gonadotropin releasing hormone analogue and minimal access surgeries. Caesarean section however, has no alternative. Caesarean section also accounts for one of the commonest operation done in obstetrics. Misgav Ladach method of LSCS, devised by Dr. M. Stark is a modification of the conventional method of caesarean section. In present study, attempt was made to assess this method in detail.

In present study majority $(50.5 \%)$ of the cases who underwent, caesarean sections were in the age group of 21-25 years (Table 1 ). In the present series the maximum number of patients who underwent caesarean sections was primigravidae $(46.5 \%)$ followed by second gravid (38.5\%), similar results were obtained by Dilip KCet al and Kshirsagar $\mathrm{N}$ et al, but in study of M Stark et al the mean age was 28.9 years in Joel Cohen's group and 29.4 years in pfannensteil's group. ${ }^{1-3}$ this difference can be explained by the early age of marriage, low education level leads to early conception.

Most common indication for LSCS in our study was foetal distress in $36 \%$ cases, Kshirsagar $\mathrm{N}$ et al found that Foetal distress accounts for $29 \%$ in Misgav Ladach method and $31 \%$ in traditional method of LSCS. ${ }^{1}$

In present study as shown in Table 3 in majority of cases (70.5) skin incision to baby delivery time is $1-2 \mathrm{~min}$ and $>4.1$ minute in only $2 \%$ cases. In a comparative study done by Kshirsagar $\mathrm{N}$ et al, time taken from skin incision to baby delivery was 1.4 minutes average in Misgav Ladach method and $2.4 \mathrm{~min}$ average in traditional method. ${ }^{1}$ Corosu $\mathrm{R}$ et al in their study used pfannensteil's incision instead of Joel Cohen's incision and average time from skin incision to baby delivery was 4.8 minute. ${ }^{4}$

In present study the mean duration of surgery was 26 minute 12 seconds, in study done by Kshirsagar $\mathrm{N}$ et al, in majority of the cases in Misgav Ladach group the time taken for surgery was 31-35 $\mathrm{min}$ and in traditional method it was 36-40 min. ${ }^{1}$ Hudic I et al observed MisgavLadach technique was associated with a shorter operative time with Joel Cohen's incision 13.3 min \pm 7.4 vs. 19.1 $\min \pm 6.8$ in pfannensteil's incision $(\mathrm{p}<0.05) .{ }^{5}$ In study done by Sharma A et al showed that total time for surgery in Misgav Ladach group was $23 \mathrm{~min}$ and in traditional method it was 35 min. ${ }^{6}$

In current study $70 \%$ patients had haemoglobin deficit $<1 \mathrm{gm} \%$ and only $1 \%$ had haemoglobin deficit $>2 \mathrm{gm} \%$. Darj E et al, compared the blood loss in Misgav Ladach technique to that in traditional method in 50 cases. $^{7}$ The 
amount of blood loss differed significantly with $448 \mathrm{ml}$ and $608 \mathrm{ml}$ in the two groups' respectively. John $\mathrm{C}$ et al 1992 , in their comparative study of one verses two layer closure of uterine incision reported $>6 \%$ haemoglobin deficit in $18 \%$ cases done by double layer closure vs. $13 \%$ cases done by single layer closure of uterus. ${ }^{8}$

In this study post operatively 4 patients were suffered from fever and 1 patient from urinary tract infection. In this method febrile morbidity is very low. In 1 patient fever is due to wound infection and in one patient is due to lower respiratory tract infection and in 2 patient causes of fever is unknown but fever subsided on its own on fourth postoperative day. Kshirsagar $\mathrm{N}$ et al, found no statistically significant differences in the post operative morbidity between the two groups in their study. ${ }^{1}$ In a study by Hudic I et al show that the febrile morbidity is less in Misgav Ladach group than compared to traditional method. ${ }^{5}$ Fritz $\mathrm{N}$ et al studied the post operative morbidity in two groups with closure and no closure of peritoneum and found that post operative morbidity was more with patients in whom peritoneum was closed. ${ }^{9}$

In current study only $5 \%$ patients had some wound complication out of which only 1 patient required secondary suturing which was comparable to Fatusic $\mathrm{Z}$ et al, found in their study that is local infection of the wound in the Misgav-Ladach group was $4.54 \%$ and in the Pfannensteil's group in $9 \%(\mathrm{p}<0.05){ }^{10}$

In present study it was observed that 2 neonatal deaths in cases where LCSC was done for foetal distress. $\mathrm{N}^{1} \mathrm{et}$ al in 2016, found no significant difference in the two groups in terms of perinatal morbidity and mortality. According to Cochrane review there was no difference in neonatal NICU admission.

\section{CONCLUSION}

Misgav Ladach technique of LSCS is developed and critically evaluated by Dr. M Stark at the Misgav Ladach hospital, Jerusalem. Joel - Cohen's incision, suturing the uterus in single layer and non closure of peritoneum forms the major modification of technique. The operating time and blood loss were noted in the study was considerably less as compared to conventional method, which may benefit the women in reducing the exposure time to anaesthesia and infective morbidity. Suturing the uterus in single layer and non closure of peritoneum results in minimal use of suture material, this decreases the post operative tissue reaction to the suture material which in turn decreases the resultant fibrosis. However, the most controversial aspect remains the single vs double layer uterine closure, in regards of the association between single layer and possible uterine rupture. Waiting for more studies to prove the efficacy and safety of single layer uterine closure, especially in relation to long term outcomes, we recommend a double-layer uterine closure.

This method is appealing for its simplicity, ease of execution and its time saving advantage. Since its shorter operating time, it is to prefer in all that cases where a prompt surgery and fast baby delivery is required.

Funding: No funding sources

Conflict of interest: None declared

Ethical approval: The study was approved by the Institutional Ethics Committee

\section{REFERENCES}

1. Kshirsagar N, Sajjan KR, Patil S, Nagur B. A study of morbidity pattern in Misgav Ladach technique of caesarean section. Int $\mathrm{J}$ Reprod Contracept Obstet Gynecol. 2016;5:1925-8.

2. Dilip KC, Dawn CS. Morbidity following caesarean section. J Obstet Gynecol India. 1985;35:1037.

3. Stark M, Chavkin Y, Kupfersztain C, Guedj P, Finkel AR. Evaluation of combination of procedures in caesarean section. Int $\mathbf{J}$ Gynecol Obstet. 1995;48:273.

4. Corosu R, Roma B, Marziali M, Di Roberto R. Modifications to the technic of cesarean section after Stark. Minerva Ginecologica. 1998 Sep;50(9):391-5.

5. Hudic I, Bujold E, Fatusic Z, Skofic F, Latifacic A, Kapidzic M, Fatusic J. The Misgav-Ladach method of caesarean section: a step forward in operative technique in obstetrics. Arch Gynecol Obstet. 2012;286(5):1141-6.

6. Sharma A, Singh M. Comparative between modified Misgav Ladach technique and pfannenstiel method of lower segment caesarean section. Natl J Med Res. 2013;3(3):286-8.

7. Darj E, Nordstorm ML. The Misgav Ladach method for caesarean section compared to the Pfannenstiel method. Acta Obstet Gynecol Scand. 1999;78(1):37.

8. Hauth JC, Owen J, Davis RO. Transverse uterine incision closure - one versus two layers. Am J Obstet Gynecol. 1992;167(4):1108-12.

9. Nagele F, Karas H, Spitzer D, Staudach A, Karasegh $\mathrm{S}$, Beck A et al. Closure or nonclosure of visceral peritoneum at caesarean delivery. Am J Obstet Gynecol. 1996;174(4):1366-70.

10. Fatušic Z, Kurjak A, Jašarevic E, Hafner T. The Misgav Ladach method--a step forward in operative technique in obstetrics. J Perinat Med. 2003;31(5):395-8.

Cite this article as: Gadappa SN, Dixit PV, Sharma D, Gavit Y. Clinical study of Misgav Ladach technique of caesarean section. Int J Reprod Contracept Obstet Gynecol 2017;6:5532-5. 